\title{
AGRICULTURAL EDUCATION AND ITS RELATION TO RURAL SOCIOLOGY
}

\author{
A. F. WOODS \\ Dean and Director, Department of Agriculture, University of Minnesota
}

THE RURAL SCHOOL

All who have investigated country-life conditions at first hand, agree that faulty education and educational methods are among the more fundamental of the limiting factors to proper social development. A very large number of those engaged in the business of farming have not reached the sixth grade in their educational work and it is estimated that even under present conditions 75 per cent of the pupils in rural schools leave school before they have finished the sixth grade. This lack of educational training is one of the most difficult conditions with which the rural life worker has to contend. It is doubtful if the average rural school of today is equal in socializing influence to the school of a generation ago. Today the rural school is taught largely by young women who have taken the normal course in a high school and are taking a country school simply as a stepping-stone to a "better position." Many of these young women may be pedagogically fairly well trained, but they have little sympathy, as a rule, with the environment in which they are living and have little knowledge of rural affairs and have little power of leadership. The young people may learn their lessons but they are not in general brought into sympathetic touch with the life about them or given the breadth of vision or the inspiration and controlling leadership that the men inspired who taught a generation ago. Under present conditions with a bare living wage there is little incentive for men and women of capacity to prepare themselves for, and continue in, rural school work. In some way or other, the boys and girls on the farm must receive this better educational training and inspiration from men and women interested in their work and who have a broad and sympathetic outlook upon rural affairs.

${ }^{2}$ Paper presented at the annual meeting of the American Sociological Society.

659 
I do not intend by this statement of the situation to imply that women are not good teachers or leaders. Some of the most effective teachers and leaders we have are women but they are women who know the country and have an interest in its problems, women who are not looking cityward but who have a vision of a new country life and who are willing to devote their life and their energy to the realization of the vision. If money were available to attract more of the right kind of teachers to the rural schools and to retain the good ones who have demonstrated their ability, the situation would quickly improve. But in many districts the financial difficulty appears to be almost insurmountable.

\section{ECONOMIC CONDITIONS}

With the rapid expansion of cultivated area, production of staple crops was for many years so much in excess of demand that prices were often below the cost of production. During that period which is just now closing, the exodus from the farm to the city has been constantly increasing, and will continue to increase until young men and women are convinced that they can make life on the farm as profitable and attractive as life in the village or city. The present generation of farmers has made more from the increase in value of land than from the profits of farming. The increased value comes not from increased fertility and producing power but from the fact that the farm has been brought nearer to market by the development of railroads and wagon roads and the increased number of consumers of agricultural products. The fact is that, in the older agricultural regions, soils once highly productive have been drawn upon by constant cropping without returning sufficient to the soil until now the soils give comparatively meager returns, yet the market price of these soils is very high compared to their original price. The young farmer of today, therefore, must pay a comparatively high price for his land, and must expend much time and money in bringing the soil back to its original producing power. This requires capital, knowledge, and experience. For the past ten years, the Minnesota Agricultural Experiment Station has been conducting a careful investigation of the cost of producing farm crops on 8I farms, distributed in different sections of the state, 
representing different types of soil, size of farms, and systems of farm management. The result of this investigation shows not only a great diversity in the capacity of the individual farmer but a great difference in the different systems of management as related to profit and loss. The more capable individuals make a good profit in addition to the interest charge on the capital invested. Some make a smaller profit, some nothing at all, and others lose money, actually using up their capital stock. The general average of the 8I farms for the period under investigation was approximately 5 per cent interest on the investment. This is significant from the viewpoint of the socialization of country life. The average represents the real social status with a fair degree of accuracy. It is clearly evident that those changes requiring money and some degree of leisure cannot be secured in a community where neither exists in a community sense. A young man starting into business therefore, if he is an average farmer, can count upon about 5 per cent interest on his investment. If he pays 6 or 8 per cent for his money, as is usually the case, it is not difficult to see where he will come out. Consequently, if he has enough education to do some figuring beforehand, he is not likely to invest in a high-priced farm unless he feels fairly certain that he has the knowledge and the skill to make a reasonable net gain in addition to interest for his labor. He will either go where he can buy good land cheap or become a tenant farmer or farm laborer or find a job in town. This condition is probably in part responsible for the relatively rapid increase in tenant farming. Whether or not it is a condition which will continue will depend largely upon the opportunity which the young man has of securing an education that will enable him to reap the largest returns from agricultural operations. A great many of the better class of farmers move to the village or town to educate their children for a life which they hope will be not quite so hard as the one the parents have lived. They usually rent their farms, and thus become a sort of landlord class. Thus much of the best life is drawn out of the country into the towns. Sometimes the family is replaced by one just as good, but more often by a family not so much interested in education or in the community. The interest 
in the individual farm is largely in what may be taken out of it. Farm life under such conditions is not attractive even to those who understand modern methods of agriculture and who know how to make farming profitable, and the home life attractive and pleasant. A few men in a backward community cannot secure the necessities that make modern life attractive-good roads, good schools, good churches, telephones, mail service, modern sanitation, and the social atmosphere. The great number of their neighbors are not interested because they do not expect to stay for long or because they cannot afford what they call "luxuries" or perhaps feel no need of them. The absent landlord objects to all these things because they mean more taxes, he has lost his direct personal interest except in his own farm and what he can get out of it in rent or shares. This is indeed the darker side of the situation. There are localities, and they are rapidly increasing in number, where the agricultural methods employed are up to date, the dominant spirit is social and progressive, the rural schools are as good as the city schools, and the rural church is a live part of the community. Good roads, telephones, mail service, rural police, and sanitary service, meet all the requirements of modern life. The homes, inside and out, are attractive and have all modern conveniences. The farms are operated on modern scientific and business principles and pay a good net profit. Co-operation flourishes in these centers and in everything essential the community acts as a unit. The great problem is how to develop this better community life in rural districts generally.

\section{EDUCATIONAL METHODS}

The first step in this process is to arouse an interest in improved methods from the standpoint of profits. The endeavor to do this through the distribution of literature as a starting-point has in the majority of cases proved unsatisfactory. As already suggested, the individuals whom it is desired to reach are not much given to reading or to understanding what they read and seldom attempt to apply suggestions that come to them in this way. Reading, however, often does arouse interest and paves the way for extension work of various kinds or leads to correspondence and closer personal 
relations. The extension work through institutes has been of great service, especially where the men who have "made good" in a district are selected as institute instructors to tell others how they did it. This work arouses interest, starts organization, and paves the way for more definite work on individual farms. The institute trains are also interest arousers but it is doubtful if the good accomplished is anywhere near equal to the good accomplished by more concentrated effort with the same cost and expenditure of energy. Work of this kind must be followed up and the interest fed if lasting good is to be accomplished. The movable schools, short courses, institutes, etc., are more effective and of greater educational value. The Farmers' Club is one of the most effective agencies through which to carry on this educational work. The Grange and other similar organizations are also most effective centers through which to work. Another type of educational effort with this end in view has been the local demonstration farm. As a rule these have been organized and managed by an expert representing either some corporation, educational institution, or the state or government. The work has been carried out with skill and the results have been clear, but the educational effect produced has been as a rule unsatisfactory. The majority of farmers have not adopted the better methods. For a long time it was difficult to understand why this should be so. It finally became apparent that the difficulty was a psychological one. The average man who came to view the demonstration farm, while fully impressed with the importance of the work, went away with a feeling that it was something beyond his capabilities. He felt that if he had a government expert and a special appropriation he might be able to accomplish something, but with his lack of resources and knowledge and the conditions on his farm to contend with, it would be impossible to make the plan work. Consequently he seldom attempted it. Those who did benefit from such farmers were as a rule those who were not so much in need of help. They could read and understand literature bearing on the subject quite as well as they could understand the plot demonstrations. It is not this better class of farmers that we are working to interest. The next step was to give less attention to state demonstration farms and more to directing the 
individual farmer in reorganizing his own farm, giving him nothing but plans and advice, and staying with him until he fully understands what is to be done, helping him gradually to readjust himself and his business according to modern scientific and business methods. Attention is first given to the more fundamental propositions, such as type of farming to follow, preparation of the land, selection of seed and stock, utilization of manure, rotation and diversification of crops, care and marketing of products, and a simple accounting and cost system. It is a comparatively easy matter to show the average farmer how he can without additional cost add 30 per cent to his yield of corn, wheat, oats, or in fact to almost any other crop he may be growing. Often the use of good seed alone is sufficient to accomplish this. The difference in cash returns at the end of the season is enough to arouse not only the interest of the farmer himself but of his neighbors also. They feel that if such results can be secured so easily by one of their own number, it will certainly pay to learn the new methods. When interest is thus aroused and tangible profits are greatly increased it becomes an easy matter to secure still further improvement in local conditions. It is easy to show how co-operative marketing adds greatly to the profits. Co-operative marketing leads into cooperative buying and other kinds of co-operative effort resulting in still greater profit. When this spirit of working together is developed, local farmers' clubs are organized. The importance of co-operative effort in the improvement of schools and roads is appreciated. Out of this grows the consolidated school which is to become the social center of the community and the directing influence of the new generation. As soon as the farmer realizes that he has some money which he can safely invest in these things he is ready to do his share. His conservatism is due, not so much to isolation as to lack of available money, and lack of money is due, as a rule, to lack of knowledge of his business. Usually his lack of knowledge is due to his lack of opportunity to get it near his home. The lack of knowledge of marketing methods has been taken advantage of by intermediaries between the producer and consumer to such an extent that it has now become one of our most serious problems. It may however be a blessing in disguise as it 
will force the producing and consuming classes to organize cooperative marketing, distributing, and buying associations. This is now taking place with great rapidity, but the middlemen do not yet see or understand.

\section{STATE AND NATIONAL ADD}

State and national aid in the improvement of roads, in drainage, the dissemination of agricultural information, and the improvement of the school system, especially along industrial lines, has been a great stimulus to improvement in many communities. Such assistance will be necessary until the more improved methods of production and marketing insure to the farmer a large enough net profit to enable him to provide unaided for local community needs. Under a system of state aid, agriculture has been introduced into the high schools in the state of Minnesota, and while the experiment is only a little more than a year old, the results have been extremely encouraging. A new interest has been awakened in the schools, the appropriations from local sources have been greatly increased, the attendance has been better, and the people of the surrounding country have taken an interest in the work. The schools have conducted short courses for the older boys and girls who could come for only a few weeks. Extension workers have gone out from the agricultural high schools to the district schools and conducted meetings and entertainments, given demonstrations of methods of selecting and testing corn, testing milk and cows, and in other practical ways helping the farmers to solve some of the more or less technical problems with which they have to deal. In some cases the agricultural high school has been made the center of a federated district, the older pupils from the rural schools being sent into the high school and the extension workers from the high school going out for extension courses to the rural schools. About 85 high schools in the state now receive state aid according to the extent of the industrial work they are doing. Similar assistance is given by the state to rural districts establishing consolidated schools. A rural school commissioner was appointed by the State Superintendent of Public Instruction and the work of organizing these schools is now in progress. Some 
35 districts have been organized within the past few months. The progress of this work is delayed by the lack of properly trained teachers and by the fear in many communities that the cost will be too great. It is incumbent upon the university, the normal schools, and high schools to exert every effort to prepare properly trained teachers for this new work and to carry on a campaign of education in its favor. Too much stress cannot be laid on the importance of insisting that agricultural work shall not be started until a thoroughly qualified teacher can be secured and the proper equipment is available. The control of this in Minnesota is in the hands of the State High-School Board. The board has ruled that only graduates of agricultural colleges can teach agriculture in the agricultural high schools.

The question is often asked, "Of how much value is school training to farmers from a business standpoint?" A recent agricultural survey of several townships of Tompkins Co., N.Y., made by the College of Agriculture of Cornell University has revealed many interesting and suggestive facts bearing upon rural sociology. To quote from the summary, "The survey shows that a high-school education is worth as much to a farmer as $\$ 6,000$ worth of 5 per cent bonds. A college education is worth nearly twice as much." A similar investigation of the graduates of the School of Agriculture of the University of Minnesota showed an average labor income of $\$ 926.7$ I. Compare this with $\$ 622$ for ordinary high-school and $\$ 847$ for ordinary college graduates, as shown by the New York investigation and $\$ 3 \mathrm{I} 8$ for the average district-school graduate. There is already rapidly developing a demand for schools of agricultural technology corresponding to the manual-training high schools of the cities. The state of Minnesota has three of these schools. They differ from the agricultural high schools in the more extended agricultural work which they are able to give, and the fact that they are associated with extensive branch experiment stations and demonstration farms. These schools are under the management of the Department of Agriculture of the university. The central school is conducted with the same faculty and equipment as the College of Agriculture, but the college and the school do not directly articulate. The aim of the college is the preparation 
of teachers and investigators by long and thorough training while the school is designed to take the young men and women from the farm after completing work in the rural school and give them a thorough training in rural affairs and in the science and art of farming and home making. The aim is to so impress them with the opportunities of farming and of rural life and to teach them how to realize the most out of these opportunities in pleasure and in profit, that they will have a strong desire to devote their lives to this kind of work. A recent investigation shows that 80 per cent of all the graduates of this school during the past 22 years are now living on farms or engaged in country life work. They are making farming profitable and pleasant. They are the centers of organization, and are having a most beneficial effect upon the communities in which they live. One of the characteristic features of these schools is the fact that the classroom and laboratory work is given during the six winter months, while the summer months are required to be spent upon the home farm putting into practice some special work assigned by the instructors. The students thus continue to help with the farm work and never lose touch with their homes. It is designed that enough of these schools shall be provided to meet the demand as it develops for a more technical agricultural education than can be secured in the agricultural high schools or in the consolidated rural schools and not so extended as the college course. One such school to five or ten counties will doubtless meet all of the requirements. These schools co-operate with the high schools, consolidated secondary and rural schools in short course and demonstration work and thus become an agricultural nucleus for the region in which they are located. All of these agencies are also working in close co-operation with the Extension Division of the Department of Agriculture of the university and this in turn is in close touch with the College of Agriculture, the Experiment Station, the state Department of Public Instruction, the national Department of Agriculture, and numerous other educational agencies. When the co-operation of all of the educational agencies is perfected, the socialization of country life according to the best American ideals can be accomplished. In all of this work the larger community interest must be aroused. 
Organized business must acknowledge its dependence in the last analysis on agriculture and must co-operate in securing for the country, good schools, good wagon roads and railroads, honest treatment in the markets and legislatures, to the end that the great basic industry may be profitable and attractive, increasing in efficiency with the increasing demands of population and civilization. So far the trained sociologist has given little attention to the rural field. The time is now at hand when such studies must be made in connection with the soil and agricultural surveys that are forming the basis of the new agriculture. 